Use of predictive habitat modelling to assess the distribution and extent of the current protection of 'listed' deep-sea habitats

Ross, Rebecca

http://hdl.handle.net/10026.1/8055

10.1111/ddi.12010

Diversity Distrib.

Wiley

All content in PEARL is protected by copyright law. Author manuscripts are made available in accordance with publisher policies. Please cite only the published version using the details provided on the item record or document. In the absence of an open licence (e.g. Creative Commons), permissions for further reuse of content should be sought from the publisher or author. 


\section{Use of predictive habitat modeling to assess the distribution and extent of the current protection of 'listed' deep-sea habitats}

Article in Diversity and Distributions · January 2012

DOI: $10.1111 /$ ddi. 12010

CITATIONS

53

2 authors:

Rebecca Eleanor Ross

University of Plymouth

11 PUBLICATIONS 75 CITATIONS

SEE PROFILE
READS

128
Kerry Louise Howell

University of Plymouth

43 PUBLICATIONS 823 CITATIONS

SEE PROFILE 
Use of predictive habitat modelling to assess the distribution and extent of the current protection of 'listed' deep-sea habitats

\section{Rebecca E. Ross \& Kerry L. Howell}

Marine Biology \& Ecology Research Centre, Marine Institute, Plymouth University, Drake Circus, Plymouth, PL4 8AA, UK 
Aim

To demonstrate the application of predictive species distribution modelling methods to habitat mapping and assessment of percentage area based conservation targets.

Location

The NE Atlantic deep sea (UK and Irish extended continental shelf limits)

Methods

MaxEnt modelling of three listed habitats (Lophelia pertusa (Linnaeus, 1758) reef (LpReef), Pheronema carpenteri (Thomson, 1869) aggregations (PcAggs), and Syringammina fragilissima (Brady, 1883) aggregations (SfAggs)), with some pre-selection of variables by Generalised Additive Modelling. Models are validated using repeated 70 / 30 build / test data splits using AUC and threshold dependent assessment methods. Predicted distribution maps are used to assess the adequacy of existing area closures for the protection of listed habitats and to assess percentage representation of each community within existing MPA networks.

\section{Results}

Model performances are rated as fair (LpReef), excellent (PcAggs), and good (SfAggs). Current closures are focused on the protection of cold water coral reef and incidentally capture some SfAggs suitable environments, but largely fail to protect PcAggs. Considering the wider network of MPAs in the study region approximately 23\% (LpReef), 2\% (PcAggs) and 6\% (SfAggs) of the area predicted as suitable for each habitat respectively is contained within an MPA.

\section{Main Conclusions}

To date decisions on area closures for the protection of 'listed' deep-sea habitats have been based on maps of recorded presence of species that are taken as being indicative of that habitat. Predictive habitat modelling may provide a useful method of better estimating the extent of listed habitats, providing direction for future MPA establishment and a means of assessing MPA network effectiveness against politically set percentage targets. Given the coarse resolution of the model these figures are likely to be lower in reality. 


\section{Introduction}

Global declines in biodiversity have ignited responses from local to international scales, aiming to establish management methods for the effective protection of species and ecosystems, and the limitation of human impact on the environment. Spatial management, through the use of Marine Protected Areas (MPAs) is contributing to efforts to meet these aims within the marine environment.

Decisions concerning locations to establish MPAs for conservation of biodiversity are generally taken on the basis of protecting species and/or habitats of perceived ecological importance, vulnerability, or rarity; specific examples of such species and habitats are often listed within the legislation requiring action to be taken. The designation of MPAs for the conservation of listed habitats requires extensive information on the spatial location and range extent of each habitat. In the deep-sea environment this data is patchy at best given the vast area, distance from shore, expense of exploration and resulting highly localised data availability relative to inshore waters (Howell et al., 2011). Efforts to map the distribution of listed habitats have resulted in maps of point sample data, often of indicator species rather than the habitat, with data dating back several decades or longer. While an extremely valuable first step, this approach has a number of drawbacks potentially resulting in the inappropriate placement of sites and an MPA network that is neither representative nor ecologically coherent.

Predictive modelling of species distributions (Bryan \& Metaxas, 2007; Holmes et al., 2007; Embling et al., 2010; Howell et al., 2011) provides a robust defensible means to "fill in the gaps" and provide complete coverage maps on which to base management decisions. Many species distribution models already exist for the reef-forming coral Lophelia pertusa (Linnaeus, 1758) in order to identify areas of conservation importance (Davies et al., 2008; Dolan et al., 2008; Guinan et al., 2009; Tittensor et al., 2009). However a recent study highlighted potential problems in using maps based on the distribution of the species, which is widespread, rather than the distribution of the habitat it forms, which is not (Howell et al., 2011). Where a habitat is the target of conservation efforts, species distribution maps produces gross overestimates of extent. It may therefore be prudent where possible to model the distribution of the habitat rather than the indicator species.

The ability to assess habitat extent can be an important tool in marine conservation efforts. Political initiatives often cite percentage targets for conservation: the 2003 IUCN Vth World Parks Congress says we must" $[\mathrm{g}]$ realty increase the marine and coastal area managed in marine protected areas by 2012; these networks should include strictly protected areas that amount to at least $20-30 \%$ of each habitat"; the 2006 Convention on Biological Diversity (CBD) also set a percentage target (10\%) for the conservation of the world's ecological regions. Thus an important secondary use of predictive habitat maps is in the assessment of conservation efforts against specified targets.

This study focuses on creating habitat model maps for three listed deep-sea habitats in part of the NE Atlantic: Lophelia pertusa reefs (LpReef; a cold-water coral reef), Pheronema carpenteri (Thomson, 1869) aggregations (PcAggs; a sponge dominated community), and Syringammina fragilissima (Brady, 1883) aggregations (SfAggs; a xenophyophore community). All three habitats qualify as 
Vulnerable Marine Ecosystems (VMEs) under United Nations General Assembly Resolution 61/105, while LpReef and PcAggs are also classed as "threatened and/or declining species and habitats" under the OSPAR Convention for the Protection of the Marine Environment of the north-east Atlantic 1992.

Lophelia pertusa is the dominant reef-building cold-water coral in the NE Atlantic with the ability to form expansive reefs and carbonate mounds up to 300m high (Roberts et al., 2006). The species may also be found as isolated colonies attached to patches of hard substrate (Wilson, 1979a; Mortensen \& Buhl-Mortensen, 2004b, a; Hovland, 2005). Globally the species may be found between 39m and $3380 \mathrm{~m}$ water depths (Thiem et al., 2006), however most reefs have been recorded between 200 and $400 \mathrm{~m}$ at temperatures between 4 and $12^{\circ} \mathrm{C}$ (Freiwald et al., 2004; Roberts et al., 2006; Davies et al., 2008). Factors driving reef formation are poorly understood but are likely to be an interplay between local hydrography and sedimentary dynamics (Thiem et al., 2006; Howell et al., 2011), with most reefs being found on topographic highs and sloping bathymetry (Strømgren, 1971; Genin et al., 1986; Frederiksen et al., 1992; Davies et al., 2008) in areas of strong currents and high productivity (Mortensen et al., 2001; White et al., 2005; Thiem et al., 2006; Kiriakoulakis et al., 2007; Davies et al., 2008).

Pheronema carpenteri is a glass sponge which can form aggregations on fine sediments with densities of up to 1.53 individuals $\mathrm{m}^{-2}$ as seen on the Goban Spur (Hughes \& Gage, 2004). These aggregations are associated with an increase in abundance and richness of macrofauna within spicule mats and sponge bodies providing habitat complexity and a hard substrate for epifauna colonisation (Rice et al., 1990; Bett \& Rice, 1992). Aggregations are found predominantly between 1000 and 1300m depth (Rice et al., 1990) in areas of high productivity, and possibly proximate to regions of enhanced bottom tidal currents which aid in re-suspension of organic matter (Rice et al., 1990; White, 2003).

Xenophyophores are found exclusively in the deep sea and can be up to $25 \mathrm{~cm}$ in diameter (Tendal, 1972, 1996; Gooday \& Tendal, 2000). Syringammina fragilissima is one of the largest and most commonly observed species in the NE Atlantic forming aggregations of up to 7-10 individuals $\mathrm{m}$ ${ }^{2}$ (Roberts et al., 2000; Bett, 2001). Sediments adjacent to large xenophyophore tests have been found to contain significantly more metazoan macrofauna than surrounding sediments (Levin et al., 1986; Levin \& Thomas, 1988) and the tests themselves can provide microhabitats for small meiofaunalsized metazoans (Gooday, 1984) and foraminifera (Gooday \& Haynes, 1983; Gooday, 1991; Shires et al., 1994). Levin $(1991,1994)$ also suggests that xenophyophore tests may provide a structural habitat for epifauna. They are often found in areas of enhanced carbon flux, on sloped topography or near topographic features (Tendal, 1972; Levin \& Thomas, 1988; Levin \& Gooday, 1992; Hughes \& Gooday, 2004).

This study aims to inform the development of deep-sea MPA networks by demonstrating the application of predictive species distribution models to habitat mapping and assessment of percentage area based targets. 
Methods

Site Description

This study considers the NE Atlantic waters of the UK and Ireland's extended continental shelf limits, excluding the Faroe Shetland Channel as a separate biogeographic region (Bett, 2001), and the North Sea due to lack of data coverage (Figure 1). Within this region there are a number of MPAs that have been primarily designated for the protection of LpReef habitat or bedrock "reef like" assemblages. These have been achieved through three different policy mechanisms resulting in three classes of MPAs: Special Areas for conservation (SACs), OSPAR MPAs, and North East Atlantic Fisheries Commission (NEAFC) closures to bottom trawling for the protection of VMEs. While the sites cannot be considered a single coherently designed MPA network they do provide the basis of a developing network and serve as a mechanism for illustrating the potential use of habitat maps in marine management.

\section{Biological Data}

Presence/absence data was compiled for each listed habitat from 222 biological video and photographic transects obtained from several research cruises undertaken in the region between 2005 and 2011 (Howell et al., 2009b; Howell et al., 2009a; Stewart et al., 2009; Howell et al., 2011; Huvenne, 2011). Additional presence/absence data for LpReef and PcAggs models were obtained from the National Oceanography Centre, Southampton programme of activities in the Porcupine Seabight (PSB) and Porcupine Abyssal Plain (PAP) between 1977 and 2000 (Rice, 1990; Rice et al., 1990; Jackson et al., 1991; Rice, 1992; Bett, 1994; Billett, 2000; Bett et al., 2001). PSB and PAP data were a combination of WASP photo-sled transects and semi-quantitative semi-balloon otter trawls (OTSB). Detailed technical specifications are available in the source literature.

\section{Environmental Data}

Environmental variables were selected based on their biological relevance, resolution and availability. Both topographic and oceanographic variables were trialled with preliminary models, however oceanographic variables were only available at 1 degree resolution (1 reading every $90 \mathrm{~km}$ ), severely degrading the resolution of the final models. Oceanographic variables were therefore excluded from the final study.

Five topographic variables were trialled with all models based on their expected significance in acting as proxies for environmental factors that drive species distributions in the deep-sea. Bathymetry (depth) provides a proxy for multiple other variables in the deep-sea including temperature (where biogeography is taken into account), current speed, water mass structure, food availability, and sediment type (Howell et al., 2002; 2010). Bathymetric data was obtained from the General Bathymetric Chart of the Oceans (GEBCO) 200830 arc-second grid, as derived from quality controlled ship soundings combined with satellite derived gravity data. This dataset provides universal 
coverage of the study area corresponding to a sounding every $750 \mathrm{~m}$ at this latitude. While finer scale multibeam bathymetry is preferable, this was not available for the entire study area.

The remaining four variables were derived from the GEBCO bathymetry layer as projected into UTM zones $27 \mathrm{~N}-30 \mathrm{~N}$. The selected derived layers isolate some of the proxy variables which may be extrapolated from bathymetry enabling better identification of variables that may be controlling habitat distribution. A review of the variables you can obtain by this method is provided by Wilson et al (2007). Slope was generated using ArcGIS v9.3.1 (ESRI, 2009) Spatial Analyst extension. Rugosity, and bathymetric position index (BPI), at broad and fine scales, were generated using ArcGIS Benthic Terrain Modeler extension (Wright et al., 2005).

Slope provides terrain gradient in degrees and serves as a proxy for the local hydrodynamic regime (Guinan et al., 2009). Enhanced current velocities and internal tides across the slope of the Porcupine Sea Bight are thought to be influential in the distribution of Pheronema carpenteri at this location (Rice et al., 1990; White, 2003), while dense Lophelia pertusa has been found to tend toward areas where the bottom slope is critical to internal waves of semidiurnal frequency (Frederiksen et al., 1992). Slope is calculated as the maximum change in elevation over the distance between a cell and its eight neighbours. Rugosity is calculated as the ratio of 3D surface area to planar area derived from a neighbourhood analysis. This acts as a measure of terrain "roughness", or structural complexity, representative of geomorphology on the scale of mesohabitats (sensu (Greene et al., 1999)), exceeding 750m in size, and substrate (Rinehart et al., 2004; Dunn \& Halpin, 2009). BPI (equivalent to topographic position index) uses neighbourhood analysis to calculate the relative elevation of a cell identifying topographic features such as ridges (positive BPI), valleys (negative BPI) and flat areas/ constant slope (0) (Weiss, 2001). BPI was generated at fine (BPIfine) and broad (BPIbroad) scales to provide separate layers defining small macrohabitats (sensu (Greene et al., 1999)), such as canyons, and large macrohabitats (sensu (Greene et al., 1999)), such as seamounts and banks. BPIfine was generated with inner radius 1, outer radius 3 (resulting in a scale factor, or sensitivity, of $2.25 \mathrm{~km}$ ), and BPlbroad was set to inner radius 1 and outer radius 33.3 (with a scale factor of $25 \mathrm{~km}$ ). Scales were determined relative to the features discernible from the GEBCO bathymetry.

All UTM projected derived layers were then merged to align with GEBCO as individual layers in WGS84 geographic projection (cell size $0.00833333^{\circ}$ ).

Modelling

Sample data was reduced to one data point per cell of environmental data. Due to the coarse resolution of the environmental data, a presence-only modelling technique was adopted as the primary basis of this study. While presence and absence data are available and used in initial Generalised Additive Models (GAMs) and threshold-based assessment of models, the inference of assured absence of a habitat within $750 \mathrm{~m}$ of the video/ image transects, where the field of view may only be a few metres wide, seemed irresponsible. 
Maximum entropy (MaxEnt) modelling is a presence-only modelling technique developed by Phillips et al $(2004 ; 2006 ; 2008)$. It has been found to be amongst the highest performing modelling techniques for presence-only modelling (Elith et al., 2006) and as such was selected for use in this study. Although MaxEnt has been found to deal well with the presence of correlated variables, Elith \& Leathwick (2009) highlight the importance of some expert pre-selection of variables to ensure relevance, however Elith (2011) warns that stricter pre-selection is unlikely to improve the model. Trials of MaxEnt models with and without pre-selection of variables found that pre-selection by GAMs and correlate removal yielded models with higher AUC and threshold-dependent metrics in the case of this study. Details of correlation testing and pre-selection of variables for use in MaxEnt models using GAMs can be found in Appendix S1 in Supporting Material.

Presence and absence data points in ArcGIS were overlaid with accompanying environmental variables and the data extracted for use in MaxEnt using the Marine Geospatial Ecology Tools add-on (Roberts et al., 2010).

MaxEnt was run using the samples-with-data (SWD) approach, with environmental data, comprising all presence and absence data, supplied in the same format. This method of "target-group" background sampling controls for sample bias and improves predictive performance (Phillips \& Dudík, 2008). Each model was run in MaxEnt version 3.3.3. Regularisation settings were trialled to reduce over-fitting (Phillips \& Dudík, 2008) resulting in a regularisation parameter of 3 for all models. Each model was then projected onto the study area environmental layer ASCIls and constrained to sampled conditions using the MaxEnt novel climates output as a mask in ArcGIS. The MaxEnt output is a logistic probability with values between 0 (low probability) and 1 (high probability). One master model was created for each listed habitat.

\section{Model Evaluation}

Presence and absence data were used to assess the final models. For each habitat model, ten randomly generated partitions of $75 \%$ training/ $25 \%$ test data were compiled manually instead of using the MaxEnt replicates setting in order to control for spatial auto-correlation within transects (Howell et al., 2011). Training and test selections were then controlled for prevalence to be approximately equivalent to the master dataset (within a range of \pm 0.01 ).

Each model was assessed using the Presence-Absence model evaluation library (Freeman, 2007) in R. Discrimination capacity was assessed using the area under the receiver operating curve (AUC). The AUC was calculated for the full model and each of the training and test datasets along with training and test average and standard deviation AUCs. Model reliability was assessed using threshold dependent model evaluation indices (Fielding \& Bell, 1997). Five thresholding methods assessed by Liu et al (2005) as "good" were considered for each model due to their tolerance to low prevalence build data: comprising sensitivity-specificity equality, sensitivity-specificity sum maximisation, and ROC-plot based approaches (Cantor et al., 1999), and prevalence, and average probability/suitability approaches (Cramer, 2003) . Each of these thresholding techniques were 
evaluated against three model performance indices: Percent Correctly Classified (PCC), specificity, and sensitivity (Fielding \& Bell, 1997; Manel et al., 1999). Average training indices and test indices were considered with full model indices to select the final thresholding method and facilitate the interpretation of modelling results (Liu et al., 2005). Jack-knife plots and variable response curves were used to assess variable importance to the final model.

Quantification of habitat distribution

MaxEnt output probability maps were transferred to ArcGIS as raster grids and masked for novel climates. The maps were then thresholded into predicted presence/absence; the ROC-plot approach was selected for all habitats. Values below the threshold were converted to a constant absence raster; values above the threshold were allowed to retain their probabilities to better inform as to relative probability of occurrence. Confidence maps based on standard deviation of cell probabilities derived from all ten partial data models, as used in the model evaluation process, were also constructed and are provided in Figure S2.

MPA Assessment

For each listed habitat, habitat presence probability maps were converted into constant rasters for ease of assessing areas in terms of raster cells. Rasters were projected into Albers Equal Area Conic with modified standard parallels (Parallel 1: $50.2^{\circ}$, Parallel 2: $58.5^{\circ}$ ) in order to standardise the area of raster cells $\left(1 \mathrm{cell}=750 \mathrm{~m}^{2}\right)$. The spatial analyst extension to ArcGIS was then used to extract areas of presence within polygons of MPA and UK and Irish continental shelf extents. All MPA and continental shelf extent polygons are based on shapefiles or coordinates obtained from governing bodies. The number of presence raster cells within an MPA is expressed as a percentage of the number of presence raster cells in the study area, and at national levels for the UK and Ireland. Table S1 contains an assessment considered by MPA type.

Results

Modelling

Output habitat suitability maps can be viewed in Figure 2. Results of variable correlation analysis and pre-selection of variables using GAMs are provided in Appendix S1 and Figure S1

Model Evaluation

Table 1 and Table 2 display the AUC values and threshold dependent model evaluation metrics for all three models.

The LpReef full model AUC score was considered good (0.8-0.9), while training and test partitions were considered good (0.8-0.9) and fair (0.7-09). The threshold value assessed by minimum ROC distance yielded good (0.8-0.9) results for full model PCC and specificity, although model sensitivity was considered fair (0.7-0.8). All training metrics, and test PCC and specificity were fair (0.7-0.8), but 
test sensitivity was poor (0.6-0.7). As a result this model was considered the worst of the three listed habitats, with a consistently lower sensitivity than specificity indicating that the model is more successful at predicting LpReef absence.

Full model, training and test AUC was excellent (0.9-1.0) for the PcAggs model. The threshold dependent metrics were also considered excellent (0.9-1.0) for full model, training and test partitions. As a result this model was considered the best of the three listed habitats.

The full SfAggs model AUC was considered excellent (0.9-1.0) while training and test partitions were excellent (0.9-1.0) and good (0.8-0.9). After thresholding full and training model PCC and specificity were considered good (0.8-0.9) and model sensitivity excellent (0.9-1.0), with average test model PCC considered good (0.8-0.9), sensitivity excellent (0.9-1.0) and specificity fair (0.7-0.8).

\section{Assessment of Variable Importance}

Jack knife tests of variable importance defined bathymetry as the most important variable to all models. The model build with bathymetry alone contributed the highest gain, while a global model excluding bathymetry experienced the greatest loss in gain. Bathymetry therefore contains the most information which cannot be accounted for by other modelled variables.

MaxEnt percent contribution estimates for the LpReef model rank variable importance as bathymetry (71.5\%), BPlbroad (21\%) and slope (7.5\%). A global model excluding slope resulted in the least reduction in gain, suggesting that slope contributed the least amount of information not implicit in other variables. Response plots of models created using only single variables suggest that LpReef may be found between 500-1200m water depths on positive broad scale topographic features and positive slopes.

The PcAggs model assigned variable importance in the order of bathymetry (60.4\%), BPIbroad $(28.1 \%)$ and rugosity (11.5\%). The importance of bathymetry was the least pronounced in this model suggesting that it is acting as a proxy for fewer unaccounted-for variables than in the other two models. Individual variable model response plots suggest that PcAggs may be found between 950$1600 \mathrm{~m}$ water depths, on broadly flat or constant slopes of low rugosity.

Heuristic estimates of variable importance in the SfAggs model rank variables as bathymetry (84.2\%), slope (12.5\%), and BPIfine (3.2\%). Although BPIfine has provided a marginal improvement in model gain, this is essentially a model reliant on bathymetry and slope. Individual variable model response plots indicate that SfAggs may be found at greater than $800 \mathrm{~m}$ water depth on negative fine scale features or constant slopes of $2^{\circ}$ or greater. The fact that no depth limit or upper slope limit is discernible suggests that the environments sampled are of insufficient range to complete the near Gaussian distribution you would expect of a habitat occurrence/variable relationship. It is also worth noting that due to the lack of PSB or PAP data the SfAggs model prediction is restricted to a depth limit of $1918 \mathrm{~m}$ and a maximum slope of $16^{\circ}$; beyond these parameters the prediction has been masked to avoid un-testable assumptions. 
MPA Assessment

Assessment of the proportion of listed habitat suitable environments included within current MPA network Table 3 found that LpReef suitable environments are the most well protected within the study area (23.2\% contained within MPAs) with protection at national levels varying from $35.6 \%$ in UK to only $12.5 \%$ in Irish waters. PcAggs are the least well protected habitat with only $2.3 \%$ of predicted suitable environments included within a current MPA, with protection at national levels varying from $3.2 \%$ in UK to $1.1 \%$ in Irish waters. SfAggs are better protected with $6.1 \%$ contained within the existing MPA network (9.6\% at UK level; $2.7 \%$ at Irish level). Measured against IUCN targets only LpReef is within the $20-30 \%$ level recommended, however it must be remembered that the current MPA network is not 'strictly protected' in line with IUCN specifications.

\section{Discussion}

Model performance and interpretation

While model performance was considered fair to excellent, all models are built on variables at the coarse resolution of GEBCO bathymetry - one depth reading every 30 arc-seconds interpreted as a cell size of $750 \mathrm{~m}^{2}$ at this latitude. As a result fine scale mesohabitats which resolve to less than $750 \mathrm{~m}$ in size, such as carbonate mounds, iceberg plough marks, and small scours which are associated with the presence of some of these listed habitats, will not be detected. For example the LpReef areas associated with iceberg plough marks in the NW Rockall bank MPA (Wilson, 1979b) have not been predicted by this model, as iceberg plough mark features measure only tens of metres in width and could not be detected. The models produced by this study must be considered in this context, providing a reference to identify areas of search, where models can be re-built on higher resolution bathymetry suited to the scale of target features (A. Rengstorf, In Press).

All other variables must also be considered in the context of the bathymetry it is derived from, and the method in which they are calculated. Slope values, for example, will vary according to the interplay between bathymetry resolution and analysis neighbourhood (Wilson et al., 2007) so the maximum $16.59^{\circ}$ recorded in this study should be considered as representative of a range inclusive of steeper gradients.

Predictions based on the GEBCO bathymetry are also likely to result in overestimation of distribution. C. Marshall et al (Submitted) found that a GEBCO $(750 \mathrm{~m})$ resolution model and a high $(50 \mathrm{~m})$ resolution model both predicted $90 \%$ of gorgonian species occurrence on Hatton Bank correctly, but the area of predicted suitable habitat presence in the GEBCO model was double the size of the higher resolution model. This difference in spatial efficiency must be taken into account, and proportions of habitat suitable environments within MPAs considered as maximum figures with the possibility of reduction by up to $50 \%$.

As models are based on topographic variables and do not include other variables explicitly, models must be considered as indications of suitable environments rather than a presence of the habitat: a 
site suited to LpReef may be found to actually constitute reef absence if, for example, it is not proximate to a larval supply sufficient to support a reef (Cowen et al., 2006). Furthermore if fluctuating conditions in non-topographic variables occur at any site the model should be regarded with this in mind. Inherently conditions do not vary considerably in the deep sea as a whole, but isolated areas may encounter fluctuating conditions. Within the study region parts of the Wyville Thomson Ridge experience fluctuations in temperature and salinity based on the periodic overflow of arctic water from the Faroe Shetland Channel (Sherwin \& Turrell, 2005).

Further model validation maybe made in comparison to the literature (locations are labelled in Figure 1 and MPAs in Figure 3(a). Known LpReef areas are largely included within current MPAs, being the primary conservation target for MPA establishment. The LpReef model successfully predicts the presence of suitable habitat where reef has been recorded in all MPAs in Irish waters including those on the Porcupine Bank and in the PSB (Kenyon et al., 1998; Foubert et al., 2005; Huvenne et al., 2005; Wheeler et al., 2007), the Logachev Mounds (Mienis et al., 2006), and the Franken Mound and Kiel Mount sites in the NEAFC West Rockall Bank Closure (Wienberg et al., 2008) (Figure 3(b)). In UK waters successful predictions included MPAs on East Rockall Bank, Anton Dohrn seamount, and the Wyville Thomson Ridge and Hatton Bank (Narayanaswamy et al., 2006; Howell et al., 2007).

The LpReef model however does not predict the presence of reef in the NW Rockall MPA, SW Rockall (Empress of Britain Bank) MPA, or the East Mingulay Reef Complex where reef is known to be present (NEAFC, 2011) (Figure 3(b)). These omissions are a direct result of the coarse resolution of model bathymetry which is unable to resolve the iceberg plough marks on Rockall (Wilson, 1979b) and rocky seafloor ridges of East Mingulay (Roberts et al., 2005), respectively attributed as influential features in reef presence at these locations. For both areas a model based on finer resolution bathymetry may better predict habitat suitability at these sites.

PcAggs have been described by Rice et al. (1990) from 1250m the Porcupine Seabight, by Le Danois (1948) from Ireland to Spain in 1000-2000m water depth, by Hughes and Gage (2004) from the Rockall-Hatton Basin at 1100m, and from 1450m on Goban Spur (Duineveld et al., 1997; Flach et al., 1998; Lavaleye et al., 2002). Historic records under its synonym Holtenia carpenteri also point to potential communities close to the Darwin Mounds MPA known then as the "Holtenia grounds" (WyvilleThomson, 1869, 1873). This model predicts all of these areas as suitable habitat for PcAggs, inclusive of an area extending southwest from the southernmost extent of the Darwin Mounds MPA (Figure 3(c)).

The SfAggs model is also further validated by records in the literature. SfAggs have been observed in the "tails" of the Darwin Mounds in 950m water at densities of up to $7 \mathrm{~m}-1$ (Bett, 2001), on the slope of the European Continental Shelf south of the Wyville Thomson Ridge at $1108 \mathrm{~m}\left(58^{\circ} 50^{\prime}-59^{\circ} 00^{\prime} \mathrm{N}\right.$, $07^{\circ} 48^{\prime}-08^{\circ} 00^{\prime} \mathrm{W}$ ) (Roberts et al., 2000) and in the Porcupine Seabight at 1340m (Gooday, 1986; Gooday \& Lambshead, 1989). The model again predicts all of these areas as suitable habitat for SfAggs (Figure 3(d)). 
Assessment of current area closures for listed habitat protection

Based on known presence data and predictive model outputs, the current MPAs do capture areas of confirmed presence and modelled high probability of occurrence of LpReef habitat (Figure 3 (b)). However known reef on George Bligh (Narayanaswamy et al., 2006; Howell et al., 2007) is not currently protected, and the model identifies many other potential areas of suitable reef habitat including the slope of the European Continental Shelf, and the flanks of other banks, seamounts and canyons such as Rosemary, Lousy, Bill Bailey, Edoras and Fangorn Banks, the Hebrides Terrace Seamount, and Whittard Canyon.

No current MPAs within the study area protect known presence of PcAggs (Figure 3(c)). However model outputs suggest that parts of the West Rockall and Logachev Mounds MPAs may include a small proportion of suitable habitat. Apart from confirmed aggregations in the PSB and Hatton-Rockall Trough the model identifies areas of potential suitable habitat in the northern Rockall Trough spanning from George Bligh bank to the Darwin Mounds and a small area between the Hebrides Terrace Seamount and the European Continental Slope.

SfAggs suitable habitat as determined by known presence and model prediction seems to be predominantly captured where current MPAs extend beyond the base of a geomorphological feature (Figure 3(d)). These incidental captures include the deepest portions of NE Rockall, Hatton Bank, Logachev Mounds and West Rockall MPAs, and a small proportion of each of the Irish cSACs. Known aggregations in the tails of the Darwin Mounds are protected by the Darwin Mounds MPA. Many areas of high probability show some overlap with areas of high probability of PcAggs in the PSB, northern Rockall Trough and between the Hebrides Terrace Seamount and the European Continental Shelf. Further unprotected areas of high probability are found on Edoras and Fangorn Banks in Irish waters, and the deeper areas of the slope of the European Continental Shelf.

Assessment of percentage area protection targets

While there are no percentage area targets set for the protection of VMEs under UNGA 61/105, and the target of $10 \%$ set by the CBD is not habitat specific, the more aspirational IUCN Vth World Parks Congress suggests that $20-30 \%$ of habitats be held within strictly protected MPAs. It is useful therefore, in the context of assessing progress in the conservation of marine habitats, to quantify the percentage of identified listed habitats contained within areas that are managed for their protection. In offshore waters this requires area estimates based on extrapolative methods. The models presented by this study provide a relatively objective method of extrapolation; using the binary map output for each habitat to provide baseline habitat spatial distribution predictions, and allow percentage estimates to be generated. While models based on higher resolution bathymetry would provide more accurate estimates (A. Rengstorf, In Press; C. Marshall et al, Submitted), in the absence of large scale coverage, these GEBCO based models may provide a basic means of assessment which could be useful to marine managers. 


\section{ACKNOWLEDGEMENTS}

The authors would like to acknowledge with thanks the scientists, officers and crew associated with the collection of data used in this study including the most recent (JC060, PSO Veerle Huvenne of NOC, Southampton), the wider Mapping the Deep and Maremap project partners, H. Stewart, J.

Davies, C. Jacobs and N. Golding, and the Marine Biological Association of the United Kingdom. This project was funded by the charitable organisations BBC Wildlife Fund and Oak Foundation under the Mapping the Deep project.

\section{Supporting Information}

Additional Supporting Information may be found in the online version of this article:

Appendix S1 \{Pre-selection of environmental variables\}

Figure S1 \{Partial-residual plots of individual variable generalised additive models\}

Figure $\mathbf{S} 2$ \{Confidence maps to accompany predictions\}

Table S1 \{Percentage estimates of current protection by MPA type\}

As a service to our authors and readers, this journal provides supporting information supplied by the authors. Such materials are peer-reviewed and may be re-organized for online delivery, but are not copy-edited or typeset. Technical support issues arising from supporting information (other than missing files) should be addressed to the authors. 
References

Bett, B.J. (1994) RRS Challenger Cruise 111, 29 Mar-25 Apr 1994. Benthic biology of the Porcupine Abyssal Plain (48,50'N 16,30'W). In. Institute of Oceanographic Sciences Deacon Laboratory, Wormley, UK.

Bett, B.J. (2001) UK-Atlantic margin environmental survey: introduction and overview of bathyal ecology. Continental Shelf Research, 21, 917-956.

Bett, B.J. \& Rice, A.L. (1992) The influence of hexactinellid sponge (Pheronema carpenteri) spicules on the patchy distribution of macrobenthos in the porcupine seabight (bathyal NE Atlantic). Ophelia, 36, 217-226.

Bett, B.J., Billett, D.S.M., Masson, D.G. \& Tyler, P.A. (2001) RRS Discovery Cruise 24807 Jul- 10 Aug 2000. A multidisciplinary study of the environment and ecology of deep-water coral ecosystems and associated seabed facies and features (The Darwin Mounds, Porcupine Bank and Porcupine Seabight). In. Southampton Oceanography Centre, Southampton, UK.

Billett, D.S.M. (2000) RRS Challenger Cruise 14219 Apr-19 May 1999. Temporal and spatial variability of benthic communities on the Porcupine Abyssal Plain and in the Porcupine Seabight. In. Southampton Oceanography Centre, Southampton, UK.

Bryan, T.I. \& Metaxas, A. (2007) Predicting suitable habitat for deep-water gorgonian corals on the Atlantic and Pacific Continental Margins of North America. Marine Ecology Progress Series, 330, 113-126.

Cantor, S.B., Sun, C.C., Tortolero-Luna, G., Richards-Kortum, R. \& Follen, M. (1999) A comparison of C/B ratios from studies using receiver operating characteristics curve analysis. Journal of Clinical Epidemiology, 52, 885-892.

Cowen, R.K., Paris, C.B. \& Srinivasan, A. (2006) Scaling of Connectivity in Marine Populations. Science, 311, 522-527.

Cramer, J.S. (2003) Logit models: from economics and other fields, Cambridge, UK.

Davies, A.J., Wisshak, M., Orr, J.C. \& Roberts, J.M. (2008) Predicting suitable habitat for the coldwater coral Lophelia pertusa (Scleractinia). Deep Sea Research, Part 1, 1048-1062.

Dolan, M.F.J., Grehan, A.J., Guinan, J.C. \& Brown, C. (2008) Modelling the distribution of cold-water corals in relation to bathymetric variables: adding spatial contact to deep-sea video. Deep Sea Research, Part 1, 1564-1579.

Duineveld, G.C.A., Lavaleye, M.S.S., Berghuis, E.M., Wilde, P.A.J.W.D., Weele, J.v.d., Kok, A., Batten, S.D. \& Leeuw, J.W.d. (1997) Patterns of benthic fauna and benthic respiration on the Celtic continental margin in relation to the distribution of phytodetritus. Internationale Revue der gesamten Hydrobiologie, 82, 395-424.

Dunn, D.C. \& Halpin, P.N. (2009) Rugoisty-based regional modelling of hard-bottom habitat. Marine Ecology Progress Series, 377, 1-11.

Elith, J. \& Leathwick, J.R. (2009) The contribution of species distribution modelling to conservation prioritization. Spatial Conservation Prioritization: Quantitative Methods \& Computational Tools (ed. by A. Moilanen, K.A. Wilson and H.P. Possingham), pp. 70-93. Oxford University Press, Oxford, UK. 
Elith, J., Phillips, S.J., Hastie, T., Dudík, M., En Chee, Y. \& Yates, C. (2011) A statistical explanation of MaxEnt for ecologists. Diversity and Distributions, 17, 43-57.

Elith, J., Graham, C.H., Anderson, R.P., Dudík, M., Ferrier, S., Guisan, A., Hijmans, R.J., Huettmann, F., Leathwick, J.R., Lehmann, A., Li, J., Lohmann, L.G., Loiselle, B.A., Manion, G., Moritz, C., Nakamura, M., Nakazawa, Y., Overton, J.M., Peterson, A.T., Phillips, S.J., Richardson, K., Scachetti-Pereira, R., Schapire, R.E., Sobero'n, J., Williams, S., Wisz, M.S. \& Zimmermann, N.E. (2006) Novel methods improve prediction of species' distributions from occurrence data. Ecography, 29, 129-151.

Embling, C.B., Gillibrand, P.A., Gordona, J., Shrimpton, J., Stevick, P.T. \& Hammond, P.S. (2010) Using habitat models to identify suitable sites for marine protected areas for harbour porpoises (Phocoena phocoena). Biological Conservation, 143, 267-279.

ESRI (2009) ArcGIS version 9.3.1.

Fielding, A.H. \& Bell, J.F. (1997) A review of methods for the assessment of prediction errors in conservation presence/absence models. Environmental Conservation, 24, 38-49.

Flach, E., Lavaleye, M., Stigter, H.d. \& Thomsen, L. (1998) Feeding types of the benthic community and particle transport across the slope of the N.W. European continental margin (Goban Spur). Progress In Oceanography, 42, 209-231.

Foubert, A., Beck, T., , Wheeler, A.J., Opderbecke, J., Grehan, A., Klages, M., Thiede, J., Henriet, J.P. \& Party, t.P.A.-X.a.S. (2005) Foubert, A., Beck, T., Wheeler, A.J., Opderbecke, J., Grehan, A., Klages, M., Thiede, J., Henriet, J.-P., the Polarstern ARK-XIX/3a Shipboard Party. Coldwater Corals and Ecosystems (ed. by A. Freiwald and J.M. Roberts), pp. 403-415. SpringerVerlag, Berlin.

Frederiksen, R., Jensen, A. \& Westerberg, H. (1992) The distribution of the scleractinian coral Lophelia pertusa around the Faeroe Islands and the relation to internal tidal mixing. Sarsia, 77, 157-171.

Freeman, E. (2007) PresenceAbsence: An R Package for Presence-Absence Model Evaluation. USDA Forest Service, Rocky Mountain Research Station.

Freiwald, A., Fossa', J.H., Grehan, A., Koslow, T. \& Roberts, J.M. (2004) Coldwater Coral Reefs. In: (ed. Unep-Wcmc), p. 84pp, Cambridge, UK.

Genin, A., Dayton, P.K., Lonsdale, P.F. \& Speiss, F.N. (1986) Corals on seamount peaks provide evidence of current acceleration over deepsea topography. Nature, 322, 59-61.

Gooday, A.J. (1984) Records of seep-sea rhizopod tests inhabited by metazoans in the North-East Atlantic. Sarsia, 69, 45-53.

Gooday, A.J. (1986) Meifaunal foraminiferans from the bathyal Porcupine Seabight (northeast Atlantic): size structure, standingstock, taxonomic composition, species diversity and vertical distribution in the sediment. Deep Sea Research, 33, 1345-1373.

Gooday, A.J. (1991) Xenophyophores (Protista, Rhizopoda) in box-core samples from the abyssal Northeast Atlantic Ocean (Biotrans area): their taxonomy, morphology and ecology. Journal of Foraminiferal Research, 21, 197-212. 
Gooday, A.J. \& Haynes, J.R. (1983) Abyssal forminifers, including two genera, encrusting the interior of Bathysiphon rusticus tubes. Deep Sea Research, 30, 591-614.

Gooday, A.J. \& Lambshead, P.J.D. (1989) Influence of seasonally deposited phytodetritus on benthic foraminiferal populations in the bathyal northeast Atlantic: the species response. Marine Ecology Progress Series, 58, 53-67.

Gooday, A.J. \& Tendal, O.S. (2000) Class Xenophyophorea. The Illustrated Guide to the Protozoa (ed. by J.J. Lee, G.F. Leedale and P. Bradbury), pp. 1086-1097. Allen Press Inc., USA.

Greene, H.G., Yoklavich, M.M., Starr, R.M., O'Connell, V.M., W.W.Wakefield, D.E.Sullivan, Jr., J.E.M. \& Cailliet, G.M. (1999) A classification scheme for deep seafloor habitats. Oceanologica acta, 22, 663-678.

Guinan, J.C., Grehan, A.J., Wilson, M.F.J. \& Brown, C. (2009) Quantifying relationships between video observations of cold-water coral and seafloor features in Rockall Trough, west of Ireland. Marine Ecology Progress Series, 375, 125-138.

Holmes, K.W., Van Niel, K.P., Kendrick, G.A. \& Radford, B. (2007) Probabilistic large-area mapping of seagrass species distributions. Aquatic Conservation: Marine Freshwater Ecosystems, 17, 385-407.

Hovland, M. (2005) Pockmark-associated coral reefs at the Kristin field off Mid-Norway. Cold-water Corals and Ecosystems (ed. by A. Freiwald and J.M. Roberts), pp. 623-632. Springer-Verlag, Heidelberg.

Howell, K.L. (2010) A benthic classification system to aid in the implementation of marine protected area networks in the deep/high seas of the NE Atlantic. Biological Conservation, 143, 10411056.

Howell, K.L., Billett, D.S.M. \& Tyler, P.A. (2002) Depth-related distribution and abundance of seastars (Echinodermata: Asteroidea) in the Porcupine Seabight and Porcupine Abyssal Plain, N.E. Atlantic. Deep-Sea Research I, 49, 1901-1920.

Howell, K.L., Davies, J.S. \& Narayanaswamy, B.E. (2009a) Identifying deep-sea megafaunal epibenthic assemblages for use in habitat mapping and marine protected area network design. Journal of the Marine Biological Association of the United Kingdom, 90, 33-68.

Howell, K.L., Davies, J.S., Hughes, D.J. \& Narayanaswamy, B.E. (2007) Strategic Environmental Assessment/ Special Area for Conservation Photographic Analysis Report. In: Strategic Environmental Assessment Report. Department of Trade and Industry, UK.

Howell, K.L., Davies, J.S., Jacobs, C. \& Narayanaswamy, B.E. (2009b) Broadscale Survey of the Habitats of Rockall Bank, and mapping of Annex I "Reef" Habitat. In. JNCC

Howell, K.L., Holt, R., Endrino, I.P. \& Stewart, H. (2011) When the species is also a habitat: Comparing the predictively modelled distributions of Lophelia pertusa and the reef habitat it forms. Biological Conservation, 144, 2656-2665.

Hughes, D.J. \& Gage, J.D. (2004) Benthic metazoan biomass, community structure and bioturbation at three contrasting deep-water sites on the northwest European continental margin. Progress in Ocenaography, 63, 29-55. 
Hughes, J.A. \& Gooday, A.J. (2004) Associations between living benthic foraminifera and dead tests of Syringammina fragilissima (Xenophyophorea) in the Darwin Mounds region (NE Atlantic). Deep Sea Research Part I, 51, 1741-1758.

Huvenne, V., Beyer, A., Haas, H.D., Dekindt, K., Henriet, J.P., Kozachenko, M., Roy, K.O.-L., Wheeler, A.J. \& Participants, T.P.a.C.c. (2005) The seabed appearance of different coral bank provinces in the Porcupine Seabight, NE Atlantic: results from sidescan sonar and ROV sea-bed mapping. Cold-water Corals and Ecosystems (ed. by A. Freiwald and J.M. Roberts), pp. 535-569. Springer-Verlag, Berlin, Heidelberg, New York

Huvenne, V.A.I. (2011) RRS James Cook Cruise 60, 09 May-12 June 2011. Benthic habitats and the impact of human activities in Rockall Trough, on Rockall Bank and Hatton Basin. In. National Oceanography Centre Southampton, Southampton, UK.

Jackson, P.A.B., Thurston, M.H. \& Rice, A.L. (1991) Station data fro the IOS Benthic Biological Survey of the Porcupine Seabight region (NE Atlantic) 1977-89. In: Institute of Oceanographic Sciences Deacon Laboratory Report (281). Institute of Oceanographic Sciences Deacon Laboratory, Wormley, UK.

Kenyon, N.H., Ivanov, M.K. \& Akhmetzhanov, A.M. (1998) Cold Water Carbonate Mounds and Sediment Transport on the Northeast Atlantic Margin. In: IOC Technical Series, p. 178pp. UNESCO

Kiriakoulakis, K., Freiwald, A., Fisher, E. \& Wolff, G.A. (2007) Organic matter quality and supply to deep-water coral/mound systems of the NW European Continental Margin. International Journal of Earth Sciences, 96, 159-170.

Lavaleye, M.S.S., Duineveld, G.C.A., Berghuis, E.M., Kok, A. \& Witbaard, R. (2002) A comparison between the megafauna communities on the N.W. Iberian and Celtic continental marginseffects of coastal upwelling? Progress In Oceanography, 2-4, 459-476.

Le Danois, E. (1948) Les profondeurs de la mer. Trente ans de recherches sur la faune sous-marine au large des côtes de France. Payot, Paris, France.

Levin, L.A. (1991) Interaction between metazoans and large, agglutinating protozoans: implications for the community structure of deep-sea benthos. American Zoology, 31, 886-900.

Levin, L.A. (1994) Paleoecology and Ecology of Xenophyophores. Palaios, 9, 32-41.

Levin, L.A. \& Thomas, C.L. (1988) The ecology of xenophyophores (Protista) on eastern Pacific seamounts. Deep Sea Research, 35, 2003-2027.

Levin, L.A. \& Gooday, A.J. (1992) Possible roles for Xenophyophores in deep-sea carbon cycling. Deep-Sea Food Chains and the Global Carbon Cycle (ed. by G.T. Rowe and V. Pariente), pp. 93-104. Kluwer, Netherlands.

Levin, L.A., DeMaster, D.J., McCann, L.D. \& Thomas, C.L. (1986) Effect of giant protozoans (class:Xenophyophorea) on deep-seamount benthos. Marine Ecology Progress Series, 29, 99-104.

Liu, C., Berry, P.M., Dawson, T.P. \& Pearson, R.G. (2005) Selecting thresholds of occurrence in the prediction of species distributions. ECOGRAPHY, 28, 385-393. 
Manel, S., Dias, J.-M. \& Ormerod, S.J. (1999) Comparing discriminatn analysis, neural networks and logistic regression for predicting species distributions: a cas study with a Himalayan river bird. Ecological Modelling, 120, 337-347.

Mienis, F., Weering, T.C.E.V., Haas, H.d., Stigter, H.d., Huvenne, V.A.I. \& Wheeler, A. (2006) Carbonate mound development at the SW Rockall Trough margin based on high resolution TOBI and seismic recording. Marine Geology, 233, 1-19.

Mortensen, P. \& Buhl-Mortensen, L. (2004a) Distribution of deep-water gorgonian corals in relation to benthic features in the Northeast Channel (Atlantic Canada). Marine Biology, 144

Mortensen, P. \& Buhl-Mortensen, L. (2004b) Deep-water corals and their habitats in The Gully, a submarine canyon off Atlantic Canada. Cold-Water Corals and Ecosystems (ed. by A. Freiwald and J.M. Roberts), pp. 247-277. Springer-Verlag, Heidelberg.

Mortensen, P.B., Hovland, M.T., Fossa ${ }^{\circ}$, J.H. \& Furevik, D.M. (2001) Distribution, abundance and size of Lophelia pertusa coral reefs in mid-Norway in relation to seabed characteristics. Journal of the Marine Biological Association of the United Kingdom, 81, 581-597.

Narayanaswamy, B.E., Howell, K.L., Hughes, D.J., Davies, J.S., Roberts, J.M. \& Black, K.D. (2006) Strategic Environmental Assessment Area 7 Photographic Analysis Report. In: Strategic Environmental Assessment Report. Department of Trade and Industry, UK.

NEAFC (2011) Recommendations VIII 2012 Closing certain areas to protect VMEs: The North-East Atlantic fisheries commission at its annual meeting in November 2011 adopted, in accordance with article 5 of the convention on future multilateral cooperation in North-East Atlantic Fisheries, a recommendation to adopt conservation and management measures by closing certain areas on the Hatton Bank, Rockall Bank, Logachev Mounds and West Rockall Mounds in the regulatory area in order to protect vulnerable marine ecosystems from significant adverse impacts in 2012. Available at: http://www.neafc.org/\%5Bfield subjectraw\%5D/5318 (accessed April 2012).

Phillips, S.J. \& Dudík, M. (2008) Modelling of Species Distributions with Maxent: New Extensions ad a Comprehensive Evaluation. Ecography, 31, 161-175.

Phillips, S.J., Dudík, M. \& Schapire, R.E. (2004) A Maximum Entropy Approach to Species Distribution Modeling. Proceedings of the 21st International Conference on Machine Learning, Banff, Canada, 2004 (ed by, pp. 655-662.

Phillips, S.J., Anderson, R.P. \& Schapire, R.E. (2006) Maximum entropy modeling of species geographic distributions. Ecological Modelling, 190, 231-259.

Rice, A.L. (1990) RRS Discovery Cruise 185, 18 August - 17 September 1989. Abyssal benthic biology at the European Community Station $\left(48,50^{\prime} \mathrm{N} 16,30^{\prime} \mathrm{W}\right)$. In. Institute of Oceanographic Sciences Deacon Laboratory, Wormley, UK.

Rice, A.L. (1992) RRS Challenger Cruise 79, 12 May - 03 June 1991. Benthic biology at the European Community Station $\left(48,50^{\prime} \mathrm{N} 16,30^{\prime} \mathrm{W}\right)$ and in the Porcupine Seabight. In. Institute of Oceanographic Sciences Deacon Laboratory, Wormley, UK. 
Rice, A.L., Thurston, M.H. \& New, A.L. (1990) Dense aggregations of a hexactinellid sponge, Pheronema carpenteri, in the Porcupine Seabight (northeast Atlantic Ocean), and possible causes. Progress in Ocenaography, 24, 179-196.

Rinehart, R.W., Wright, D.J., Lundblad, E.R., Larkin, E.M., Murphy, J. \& Cary-Kothera, L. (2004) ArcGIS 8.x Benthic Terrain Modeler: Analysis in American Samoa. In: 24th Annual ESRI User Conference, San Diego, USA.

Roberts, J.J., Best, B.D., Dunn, D.C., Treml, E.A. \& Halpin, P.N. (2010) Marine Geospatial Ecology Tools: An integrated framework for ecological geoprocessing with ArcGIS, Python, $R$, MATLAB, and C++. Environmental Modelling \& Software, 25, 1197-1207.

Roberts, J.M., Wheeler, A.J. \& Freiwald, A. (2006) Reefs of the deep: the biology and geology of coldwater coral ecosystems. Science 312, 543-547.

Roberts, J.M., Brown, C.J., Long, D. \& Bates, C.R. (2005) Acoustic mapping using a multibeam echosounder reveals cold-water coral reefs and surrounding habitats Coral Reefs, 24, 654669.

Roberts, J.M., Harvey, S.M., Lamont, P.A., Gage, J.D. \& Humphery, J.D. (2000) Seabed photography, environmental assessment and evidence for deep-water trawling on the continental margin west of the Hebrides. Hydrobiologia, 441, 173-183.

Sherwin, T.J. \& Turrell, W.R. (2005) Mixing and advection of a cold water cascade over the WyvilleThomsonRidge. Deep Sea Research I: Oceanographic Reasearch Papers, 52, 13921413.

Shires, R., Gooday, A.J. \& Jones, A.R. (1994) The morphology and ecology of an abundant new komokiacean mudball (Komokiacea, Foraminiferida) from the bathyal and abyssal NE Atlantic. Journal of Foraminiferal Research, 24, 214-225.

Stewart, H., Davies, J.S., Long, D., Strömberg, H. \& Hitchen, K. (2009) JNCC Offshore Natura Survey: Anton Dohrn Seamount and East Rockall Bank. In. JNCC

Strømgren, T. (1971) Vertical and horizontal distribution of Lophelia

pertusa (LINNE' ) in Trondheimsfjorden on the west coast of Norway. Det Kongelige Norske Videnskabers Selskabs Skrifter, 6, 1-9.

Tendal, O.S. (1972) A monograph of the Xenophyophoria (Rhizopodea, Protozoa). Galathea Report, 12, 7-103.

Tendal, O.S. (1996) Synoptic checklist and bibliography of the Xenophyophorea (Protista), with a zoogeographical survey of the group. Galathea Report, 17, 79-101.

Thiem, Ø., Ravagnan, E., Fossa ${ }^{\circ}$, J.H. \& Berntsen, J. (2006) Food supply mechanisms for cold-water corals along a continental shelf edge. Journal of Marine Systems, 26, 1481-1495.

Tittensor, D.P., Baco, A.R., Brewin, P.E., Clark, M.R., Consalvey, M., Hall-Spencer, J., Rowden, A.A., Schlacher, T., Stocks, K. \& Rogers, A.D. (2009) Predicting global habitat suitability for stoy corals on seamounts. Journal of Biogeography, 36, 1111-1128.

Weiss, A.D. (2001) Topographic positions and landforms analysis. In: ESRI International User Conference, San Diego, USA. 
Wheeler, A., Beyer, A., Freiwald, A., Haas, H.d., Huvenne, V.A.I., Kozachenko, M., Roy, K.O.-L. \& Opderbecke, J. (2007) Morphology and environment of cold-water coral carbonate mounds on the NW European margin. International Journal of Earth Sciences, 96, 37-56.

White, M. (2003) Comparison of near seabed currents at two locations in the Porcupine Sea Bight -implications for benthic fauna. Journal of the Marine Biological Association of the United Kingdom, 83, 683-686.

White, M., Mohn, C., H, d.S. \& Mottram, G. (2005) Deep-water coral development as a function of hydrodynamics and surface productivity around the submarine banks of the Rockall Trough, NE Atlantic. Cold-Water Corals and Ecosystems (ed. by A. Freiwald and J.M. Roberts), pp. 503-514. Springer, Berlin/Heidelberg.

Wienberg, C., Beuck, L., Heidkamp, S., Hebbeln, D., Freiwald, A., Pfannkuche, O. \& Monteys, X. (2008) Franken Mound: facies and biocoenoses on a newly-discovered "carbonate mound" on the western Rockall Bank, NE Atlantic Facies, 54, 1-24.

Wilson, J.B. (1979a) "Patch" development of the deep-water coral Lophelia pertusa (L.) on Rockall Bank. Journal of the Marine Biological Association, 59, 165-177.

Wilson, J.B. (1979b) The distribution of the coral Lophelia pertusa (L.) [L. prolifera (Pallas)] in the North-Easth Atlantic. Journal of the Marine Biological Association of the United Kingdom, $\mathbf{5 9}$, 149-164.

Wilson, M.J., O'Connell, B., Brown, C., Guinan, J. \& Grehan, A.J. (2007) Multiscale terrain analysis of multibeam bathymetry data for habitat mapping on the continental slope. Marine Geodesy, $\mathbf{3 0}$, 3-35.

Wright, D.J., Lundblad, E.R., Larkin, E.M., Rinehart, R.W., Murphy, J., Cary-Kothera, L. \& Draganov, K. (2005) ArcGIS Benthic Terrain Modeler. Oregon State University, Davey Jones Locker Seafloor Mapping/Marine GIS Laboratory and NOAA Coastal Services Center.

WyvilleThomson, C. (1869) On Holtenia, a genus of vitreous sponges. Philosophical Transactions of the Royal Society, 159, 701-720.

WyvilleThomson, C. (1873) The Depths of The Sea. Macmillan and co, London. 


\section{Biosketch}

Rebecca Ross is a marine ecologist who currently focuses on the deep-sea. Her primary interests are in marine conservation solutions, habitat mapping, predictive modelling, the use of underwater video in ecology, and applied inter-disciplinary ecology.

Kerry Howell is a deep-sea benthic ecologist whose research interests are focused on providing the science to support sustainable management and conservation of deep-sea ecosystems. Current areas of focus are habitat mapping, predictive habitat distribution modelling, larval dispersal modelling, population connectivity and depth related patterns of faunal zonation.

\section{Author contributions:}

K.H. conceived the ideas; K.H. and R.R. collected the data; R.R. analysed the data; and R.R. led the writing with input from $\mathrm{KH}$. 
Table 1 Threshold independent area under the curve (AUC) indices for all three listed habitat models: LpReef = Lophelia pertusa (Linnaeus, 1758) reef, PcAggs = Pheronema carpenteri (Thomson, 1869) aggregations, SfAggs= Syringammina fragilissima (Brady, 1883) aggregations.

\begin{tabular}{|c|c|c|c|c|c|c|c|c|c|}
\hline \multicolumn{2}{|c|}{ Habitat LpReef } & \multicolumn{3}{|c|}{ PcAggs } & \multicolumn{5}{|c|}{ SfAggs } \\
\hline Model & Training & Test & FullModel & Training & Test & FullModel & Training & Test & FullModel \\
\hline 1 & 0.8 & 0.85 & 0.86 & 0.99 & 0.98 & 0.99 & 0.93 & 0.93 & 0.93 \\
\hline 2 & 0.84 & 0.69 & & 0.99 & 0.99 & & 0.92 & 0.92 & \\
\hline 3 & 0.79 & 0.85 & & 0.98 & 1.00 & & 0.92 & 0.89 & \\
\hline 4 & 0.8 & 0.81 & & 0.99 & 1.00 & & 0.93 & 0.86 & \\
\hline 5 & 0.81 & 0.72 & & 0.98 & 0.99 & & 0.9 & 0.96 & \\
\hline 6 & 0.83 & 0.74 & & 0.99 & 0.97 & & 0.93 & 0.89 & \\
\hline 7 & 0.83 & 0.74 & & 0.99 & 0.99 & & 0.94 & 0.82 & \\
\hline 8 & 0.8 & 0.8 & & 0.99 & 1.00 & & 0.96 & 0.78 & \\
\hline 9 & 0.86 & 0.64 & & 1.00 & 0.94 & & 0.94 & 0.89 & \\
\hline 10 & 0.84 & 0.69 & & 0.99 & 1.00 & & 0.92 & 0.94 & \\
\hline Average & 0.82 & 0.75 & & 0.99 & 0.99 & & 0.93 & 0.89 & \\
\hline SD & 0.02 & 0.07 & & 0.00 & 0.02 & & 0.01 & 0.05 & \\
\hline
\end{tabular}


Table 2 Threshold dependent model evaluation metrics for (a) Lophelia pertusa (Linnaeus,1758) reef, (b) Pheronema carpenteri (Thomson,1869) aggregations, (c) Syringammina fragilissima (Brady,1883) aggregations. The ROC-plot based method (MinROCdist) was selected for all models, although note this always recommended the same full model threshold as the sensitivity-specificity sum maximisation approach (MaxSens+Spec). Metrics are percent correctly classified (PCC), sensitivity (sens.), and specificity (spec.).

\section{(a)}

Approach

Sens $=$ Spec

MaxSens+Spec

ObsPrev

MeanProb

MinROCdist

\section{Average Training}

\section{PCC (sd)}

$0.75(0.02)$

$0.79(0.01)$

$0.33(0.02)$

$0.79(0.01)$

$0.79(0.01)$
Sens. (sd)

$0.76(0.05)$

$0.75(0.05)$

$1.00(0.00)$

$0.75(0.05)$

$0.75(0.05)$

\section{Average Test}

Spec. (sd) PCC (sd)

$0.75(0.02)$

$0.80(0.01)$

$0.27(0.02)$

$0.79(0.02)$

$0.79(0.02)$

\section{$0.70(0.03)$}

$0.76(0.02)$

$0.35(0.03)$

$0.48(0.03)$

$0.75(0.03)$
Sens. (sd)

$0.69(0.09)$

$0.69(0.08)$

$0.96(0.02)$

$0.83(0.06)$

$0.69(0.09)$

\section{Full Model}

Spec. (sd) PCC sens. Spec. Threshold

$\begin{array}{lllll}0.70(0.03) & 0.76 & 0.77 & 0.76 & 0.45\end{array}$

$\begin{array}{lllll}0.77(0.03) & 0.82 & 0.75 & 0.82 & 0.48\end{array}$

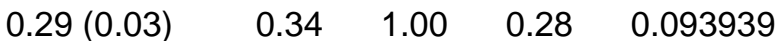

$\begin{array}{lllll}0.44(0.03) & 0.60 & 0.95 & 0.57 & 0.314008\end{array}$

$\begin{array}{lllll}0.75(0.03) & 0.82 & 0.75 & 0.82 & 0.48\end{array}$ 
(b)

\section{Approach}

Sens $=$ Spec

MaxSens+Spec

ObsPrev

MeanProb

MinROCdist

(c)

\section{Approach}

Sens=Spec

MaxSens+Spec

ObsPrev

MeanProb

MinROCdist

\section{Average Training}

PCC (sd) Sens. (sd)

$0.96(0.01)$

$0.96(0.03)$

$0.94(0.01)$

$0.98(0.02)$

$0.88(0.01)$

$1.00(0.00)$

$0.89(0.01)$

$0.99(0.01)$

$0.96(0.01)$

$0.98(0.02)$

\section{Average Training}

$0.84(0.02) \quad 0.83(0.07)$

$0.80(0.02) \quad 0.95(0.03)$

$0.54(0.03) \quad 1.00(0.00)$

$0.70(0.02) \quad 1.00(0.00)$

$0.83(0.02) \quad 0.90(0.06)$
Average Test

Spec. (sd)

$0.93(0.01)$

$0.87(0.01)$

$0.88(0.01)$

$0.95(0.01)$

\section{PCC (sd)}

$0.96(0.01)$

0.96 (0.01)

$0.90(0.02)$

$0.91(0.02)$

$0.96(0.01)$
$0.95(0.01)$

\section{Full Model}

$\begin{array}{llllll}\text { Sens. (sd) } & \text { Spec. (sd) } & \text { PCC } & \text { sens. } & \text { Spec. } & \text { Threshold } \\ 0.97(0.03) & 0.96(0.01) & 0.95 & 0.94 & 0.95 & 0.2 \\ 0.99(0.01) & 0.95(0.01) & 0.97 & 0.94 & 0.97 & 0.275 \\ 0.99(0.01) & 0.90(0.02) & 0.90 & 0.98 & 0.90 & 0.065772 \\ 0.99(0.01) & 0.90(0.02) & 0.91 & 0.98 & 0.90 & 0.073722 \\ 0.99(0.01) & 0.96(0.01) & 0.95 & 0.96 & 0.95 & 0.19\end{array}$

Average Test

Full Model

$\begin{array}{llllllll}\text { Spec. (sd) } & \text { PCC (sd) } & \text { Sens. (sd) } & \text { Spec. (sd) } & \text { PCC } & \text { sens. } & \text { Spec. } & \text { Threshold } \\ 0.84(0.02) & 0.79(0.03) & 0.78(0.12) & 0.80(0.03) & 0.85 & 0.85 & 0.85 & 0.39 \\ 0.79(0.02) & 0.78(0.03) & 0.97(0.02) & 0.76(0.03) & 0.82 & 0.93 & 0.81 & 0.31 \\ 0.51(0.03) & 0.56(0.04) & 1.00(0.00) & 0.52(0.04) & 0.60 & 1.00 & 0.57 & 0.076628 \\ 0.68(0.03) & 0.70(0.04) & 0.97(0.02) & 0.68(0.04) & 0.73 & 0.98 & 0.71 & 0.191233 \\ 0.83(0.02) & 0.80(0.03) & 0.92(0.06) & 0.79(0.03) & 0.82 & 0.93 & 0.81 & 0.31\end{array}$


Table 3 Percentages of predicted suitable environments for each listed habitat currently protected within the wider MPA network and by national jurisdiction (compared to predicted suitable habitat presence only within national waters). A further breakdown by MPA establishing authority is also available in the supplementary material.

\section{Habitat}

Lophelia pertusa (Linnaeus,1758) reef

Pheronema carpenteri (Thomson,1869) aggregations

Syringammina fragilissima (Brady,1883) aggregations

\section{MPA wider network}

$23.2 \%$

$2.3 \%$

$6.1 \%$

\section{MPA in UK Waters}

$35.6 \%$

$3.2 \%$

$9.6 \%$
MPA in Irish Waters

$12.5 \%$

$1.1 \%$ 
List of Figure captions:

\section{Figure 1}

Study Area. Black outlines and continuous greyscale bathymetry mark the study area which comprises the NE Atlantic extents of the UK and Irish extended continental shelf regions. The dotted perimeter line shows the additional extent of the UK waters into the Faroe Shetland Channel and the North Sea, which are not included in this study. Seabed features are labelled with additional features as follows: 1 - Hebrides Terrace Seamount, 2 - Anton Dohrn Seamount, 3 - George Bligh Bank, 4 Darwin Mounds (NE Rockall Trough), 5 - Wyville Thomson Ridge, 6 - Bill Bailey's Bank, 7 - Faroe Bank. Bathymetry outside the study area is displayed as $200 \mathrm{~m}$ isobaths to $1000 \mathrm{~m}$ depth, then at $500 \mathrm{~m}$ intervals. Map projected in Albers Equal Area Conic with modified standard parallels (parallel 1 $=50.2^{\circ}$, parallel $2=58.5^{\circ}$.

\section{Figure 2}

Full model prediction maps for (a) Lophelia pertusa (Linnaeus, 1758) reef, (b) Pheronema carpenteri (Thomson, 1869) aggregations, and (c) Syringammina fragilissima (Brady, 1883) aggregations. Threshold values, and medium and high probability value ranges for each habitat are as follows: (a) threshold 0.48, medium 0.48-0.58, high 0.59-0.86; (b) threshold 0.19, medium 0.19-0.55, high 0.550.93; (c) threshold 0.31, medium 0.31-0.57, high 0.58-0.78. Where white background is visible, prediction has been masked due to novel climates. Maps projected in Albers Equal Area Conic with modified standard parallels (parallel $1=50.2^{\circ}$, parallel $2=58.5^{\circ}$ ).

\section{Figure 3}

MPA Assessment. (a) Current MPAs considered during this study: 1- Hatton Bank pSAC and NEAFC Closure, 2- Darwin Mounds cSAC, 3- Wyville Thompson Ridge cSAC, 4- NW Rockall cSAC and NEAFC Closure, 5- East Rockall Bank pSAC, 6- Anton Dohrn pSAC, 7- East Mingulay cSAC (Inshore), 8- West Rockall NEAFC Closure, 9- Haddock Box NEAFC Closure, 10- SW Rockall (Empress of Britain Bank) NEAFC Closure, 11- Logachev Mounds NEAFC Closure, 12- NW Pocupine Bank CSAC, 13- SW Porcupine Bank cSAC, 14- Hovland Mound Province CSAC, 15- Belgica Mound Province cSAC. Subsequent maps, constructed from binary predictions, display only presence of predicted suitable habitat for (b) Lophelia pertusa (Linnaeus, 1758) reef, (c) Pheronema carpenteri (Thomson, 1869) aggregations, and (d) Syringammina fragilissima (Brady, 1883) aggregations with predicted presence within an MPA highlighted as black. Isobaths are every $200 \mathrm{~m}$ to $1000 \mathrm{~m}$ depth, then at $500 \mathrm{~m}$ intervals. Maps projected in Albers Equal Area Conic with modified standard parallels (parallel $1=50.2^{\circ}$, parallel $2=58.5^{\circ}$ ).

\section{Figure S1}

Partial-residual plots of generalised additive models built with one of the five individual variables against the presence of (a) Lophelia pertusa (Linnaeus, 1758) reef, (b) Pheronema carpenteri (Thomson, 1869) aggregations, and (c) Syringammina fragilissima (Brady, 1883) aggregations, as 
undertaken for variable pre-selection. Plots are centred on the no relationship zero line, with predictive capacity expressed by deviance from this line: greater than zero is a predicted presence, less than zero a predicted absence. Dotted lines are $95 \%$ confidence intervals, rugs along the $x$-axis mark the spread of sample values.

\section{Figure S2}

Confidence maps displaying the standard deviation of predicted presence values between the ten training/test build models for (a) Lophelia pertusa (Linnaeus, 1758) reef, (b) Pheronema carpenteri (Thomson, 1869) aggregations, and (c) Syrinammina fragilissima (Brady, 1883) aggregations. Low and high SD values in each model correspond with the following value ranges: (a) low 0.01-0.08, high 0.09-0.24; (b) low 0.02-0.15, high 0.16-0.26, (c) low 0.02-0.07, high 0.08-0.18. 


\section{Supporting Information}

Appendix S1 Pre-selection of environmental variables

The statistical software environment R, version 2.13.1 (R Development Core Team, 2011) was used to run a Pearson correlation test to identify correlated variables. Rugosity and slope were considered highly correlated for all models (0.95) while BPIbroad and BPIfine were moderately correlated for all models (0.51).

Binomial Generalised Additive Models (GAMs) were run with the logit link function in R using the MGCV library (Wood, 2011), employing 4 knots and a gamma of 1.4 to reduce over fitting as advocated by Kim \& Gu (2004). This process identified variables which showed no significant relationship with listed habitat occurrence. These variables were excluded from the final MaxEnt model. Partial residual plots were also examined and relationships considered for biological relevance and reliability in terms of $95 \%$ confidence intervals.

The dredge function within the MuMIn library in $\mathrm{R}$ (Barton, 2012) was then used to explore a variety of global GAMs containing only one of each correlate set. This process highlighted which variable combinations would produce the strongest models and further confirmed the prudence of excluding insignificant variables identified by the individual GAMs. The model containing the most variables within 2 corrected Aikike's Information Criterion, or AICc, (delta <2) of the top ranked model was employed as the variable combination used for MaxEnt.

\section{Results of variable pre-selection process}

The partial residual plots of individual variable GAMs for each habitat can be seen in Figure S1.

Individual variable GAMs found that all variables had a significant $(\mathrm{p}<0.05)$ relationship with Lophelia pertusa (Linnaeus, 1758) reef (LpAggs) occurrence. However examination of partial residual plots revealed that BPIfine, rugosity, and slope were displaying no relationship in the areas of highest confidence, while at values of low confidence $95 \%$ intervals remained inclusive of the no relationship 0 -line. Dredge results indicated that a global model inclusive of bathymetry, BPIbroad, and slope would yield the highest AICc score when correlates have been removed (AICC 263.6, with next best 291.6).

All variables had a significant $(p<0.05)$ relationship with Pheronema carpenteri (Thomson, 1869) aggregation occurrence with bathymetry and BPIbroad of highest significance $(p=0)$. Examination of partial residual plots revealed possible relationships with bathymetry, rugosity and slope, while BPIbroad and BPIfine displayed wide confidence intervals with little discernible relationship to Pheronema carpenteri aggregation occurrence. Dredge results indicated that a model inclusive of bathymetry, BPIbroad, and rugosity would yield the highest AICc when correlates have been removed (AICc 100.5, with next best 103.9). 
Bathymetry and BPIbroad had a significant $(p<0.05)$ relationship with Syringammina fragilissima (Brady, 1883) aggregation occurrence, with slope and BPIfine $(p<0.1)$, and rugosity $(p=0.208)$ considered insignificant. Examination of partial residual plots revealed discernible relationships with bathymetry, BPIbroad, and a linear relationship with BPIfine. Dredge results found that a global model inclusive of bathymetry, fine scale BPI and slope yielded equal AICc to a model substituting broad scale BPI with correlates removed (AICc 197.4). Global GAMs were therefore examined further for smooth term significance. Neither BPIbroad $(p=0.65)$ nor BPIfine $(p=0.99)$ were considered significant terms themselves, however the fine scale model resulted in significant $(p<0.05)$ terms for bathymetry and slope, while the broad scale model reduced the slope smooth term to insignificant $(p=0.0729)$. Final variable selection was made on the basis of trialling both BPI models with MaxEnt. MaxEnt variable response plots indicated that the bathymetry, BPIfine, and slope construction had a greater impact on full model performance than the BPlbroad build which appeared to have no effect. The similarity in BPI models and the difference between individual variable responses and within model responses stresses the complexity of variable interactions. The difference between the results of modelling techniques is likely due to GAMs being a presence/absence models and MaxEnt a presence-only model. 
Appendix S1 References

Barton, K. (2012) MuMIn: multi-model inference. In: R package version >= 2.12.0.

Kim, Y.-J. \& Gu, C. (2004) Smoothing spline Gaussian regression: more scalable computation via efficient approximation. Journal of the Royal Statistical Society B, 66, 337-356.

R Development Core Team (2011) R: A Language and Environment for Statistical Computing. R Foundation for Statistical Computing.

Wood, S.N. (2011) Fast stable restricted maximum likelihood and marginal likelihood estimation of semiparametric generalized linear models. Journal of the Royal Statistical Society (B), 73, 3 36. 
Table S1 Percentage estimates of currently protected areas with a suitable environment for Lophelia pertusa (Linnaeus, 1758) Reef (LpReef), Pheronema carpenteri (Thomson, 1869) aggregations (PcAggs), Syringammina fragilissima (Brady, 1883) aggregations (SfAggs). Percentages are estimated against total predicted presence of suitable environments in the full study area (UK and Irish waters), or by national jurisdiction. MPA $=$ marine protected area, NEAFC closure $=$ North-East Atlantic Fisheries Commission closure, cSAC = candidate Special Area of Conservation, pSAC = possible Special Area of Conservation.

Predicted presence UK and Irish waters

In any MPA (cSAC, pSAC or NEAFC closures)

In NEAFC closures

\section{Predicted presence UK waters}

In any UK MPA (cSAC, pSAC and NEAFC closures)

In UK cSACs

UK pSACs

Predicted presence Irish Waters

In any Irish MPA (cSAC and NEAFC closures)

In Irish cSACs

$\begin{array}{lll}\text { LpReef } & \text { PcAggs } & \text { SfAggs } \\ 23.2 \% & 2.3 \% & 6.1 \% \\ 17.1 \% & 1.9 \% & 3.7 \%\end{array}$

LpReef

PcAggs

SfAggs

$35.6 \%$

$3.2 \%$

$9.6 \%$

$1.3 \%$

$0.2 \%$

$0.9 \%$

$33.1 \%$

$1.8 \%$

$7.0 \%$

PcAggs

SfAggs

$12.5 \%$

$1.1 \%$

$2.7 \%$

$4.5 \%$

$0.0 \%$

$0.7 \%$ 
Figure 1 Site Description

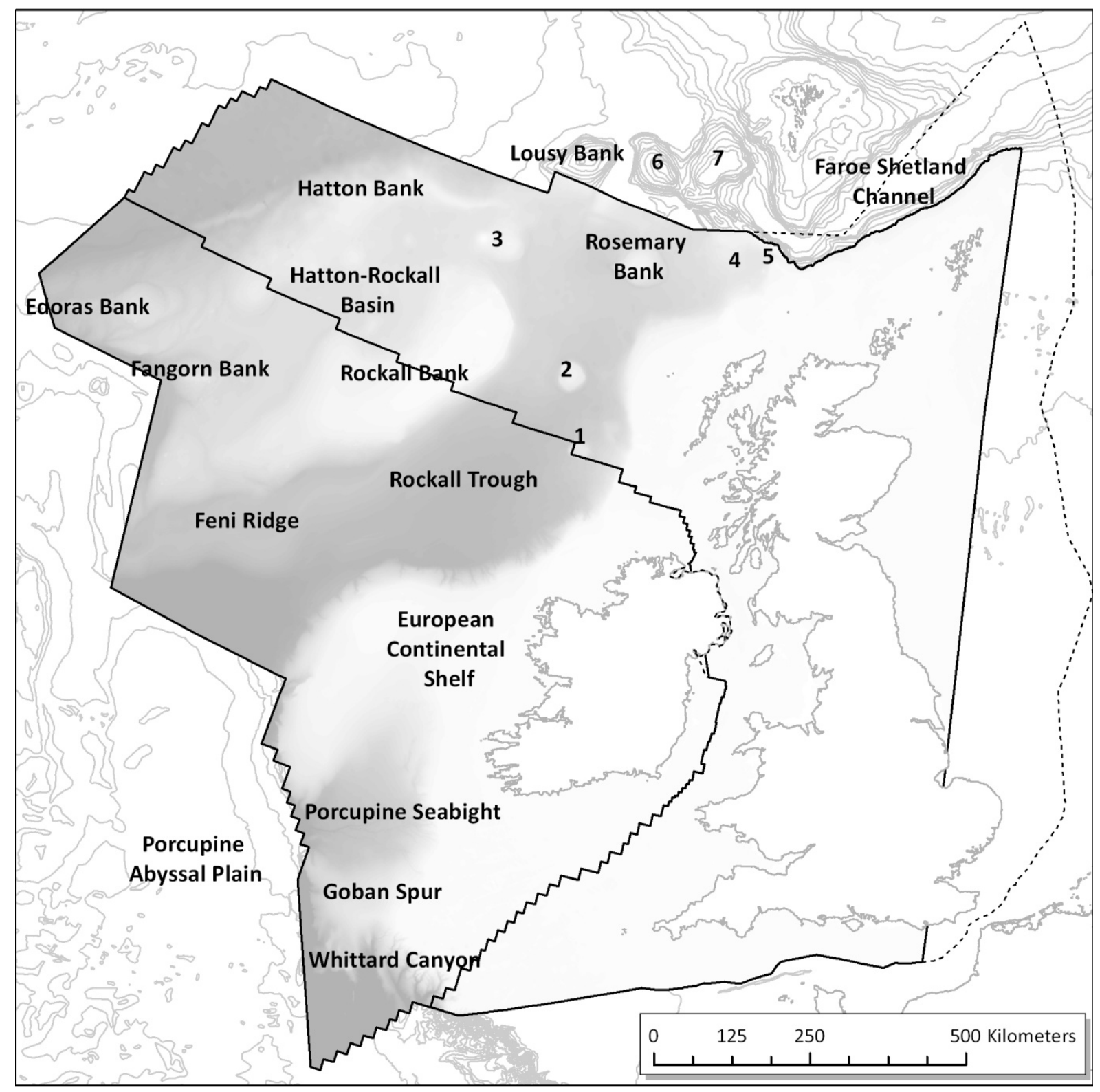


Figure 2 Prediction Maps
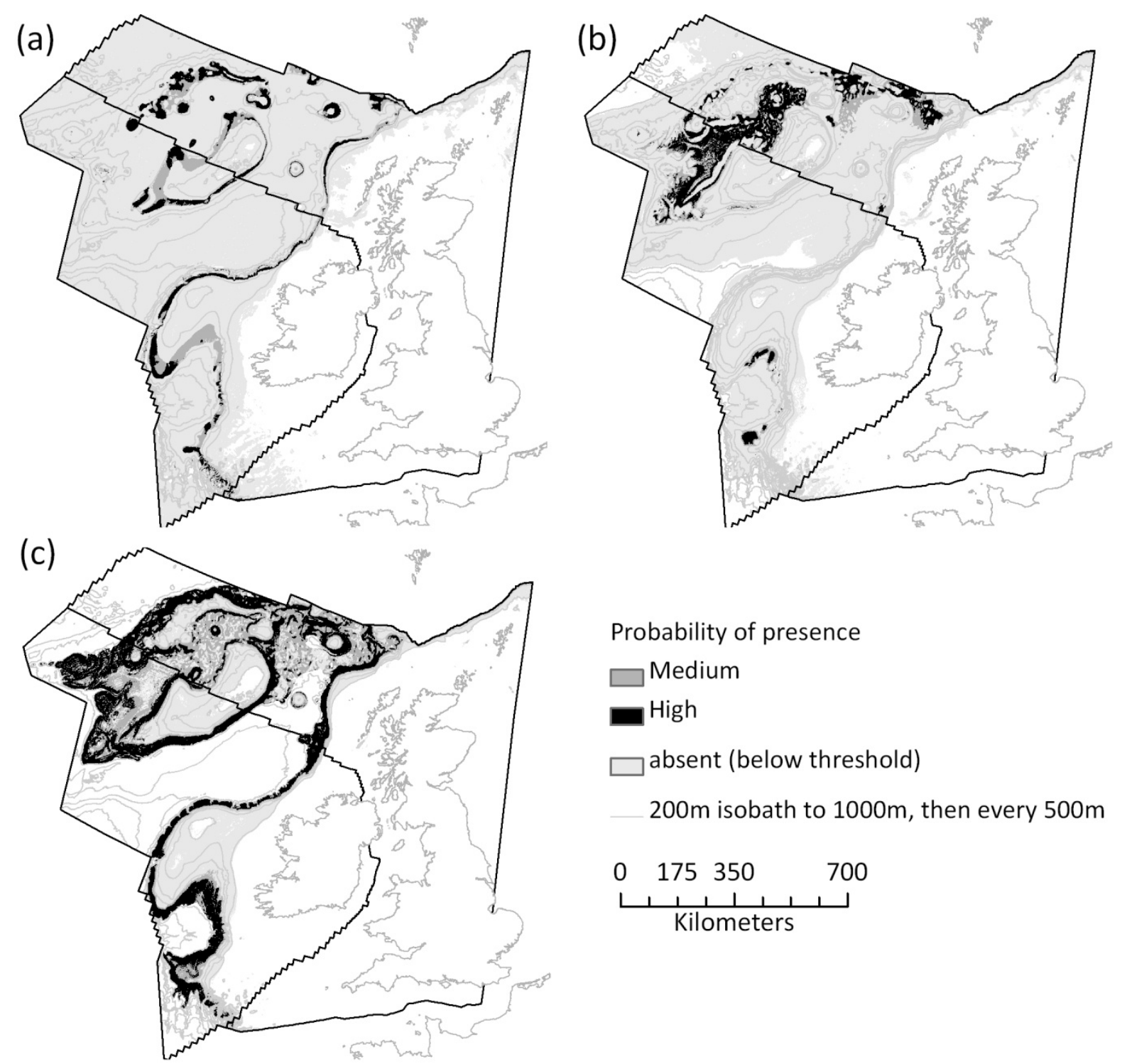

Probability of presence

$\square$ Medium

- High

$\square$ absent (below threshold)

$200 \mathrm{~m}$ isobath to $1000 \mathrm{~m}$, then every $500 \mathrm{~m}$

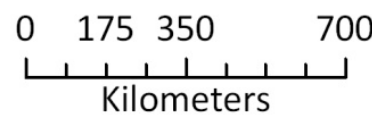


Figure 3 MPA Assessment Maps
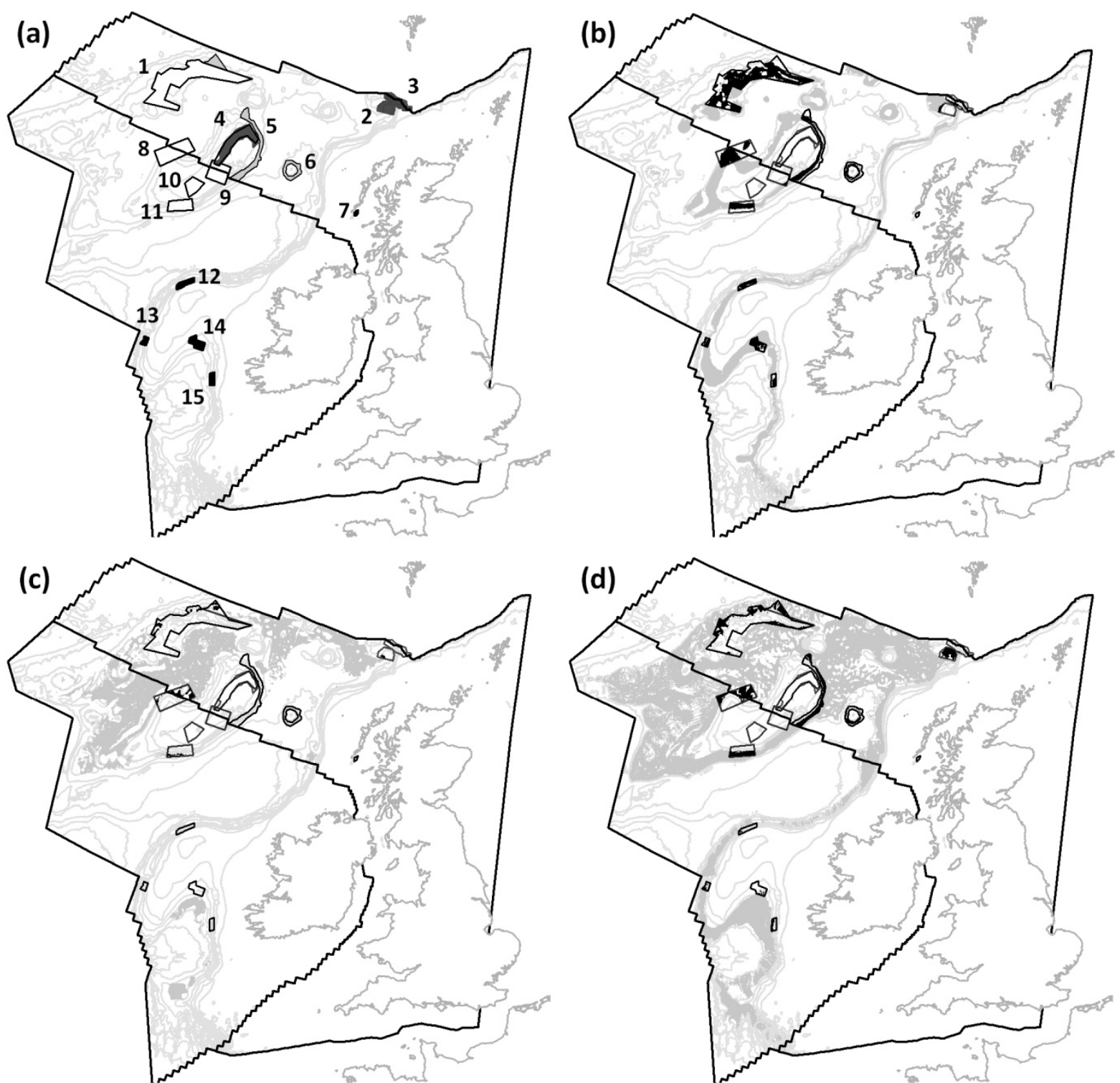

(a)

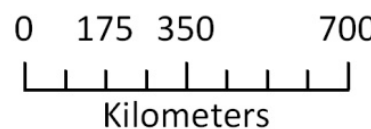

(b) - (d)

candidate SAC NEAFC closure possible SAC
Suitable habitat within an MPA

$\square$ Suitable habitat outside an MPA 
Figure S1 Variable pre-selection by generalised additive modelling

(a)

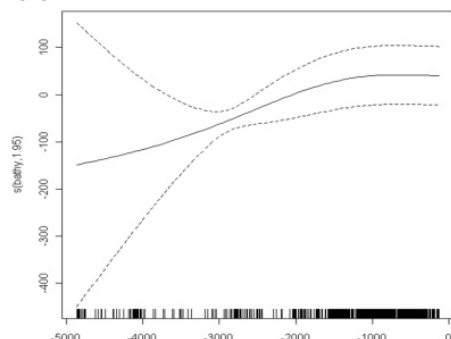

(b)

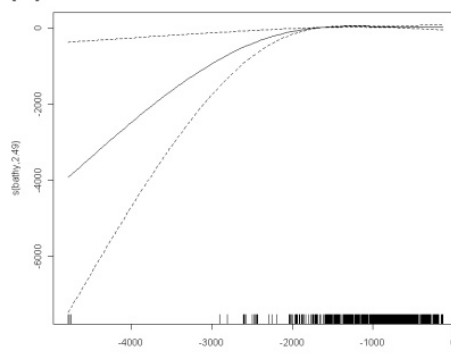

(c)

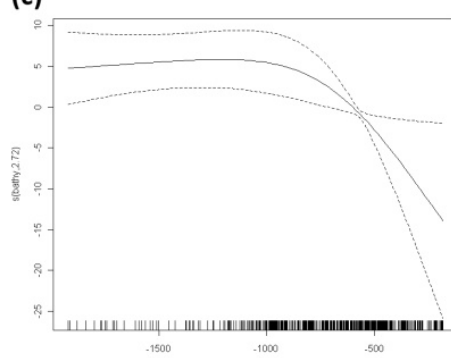

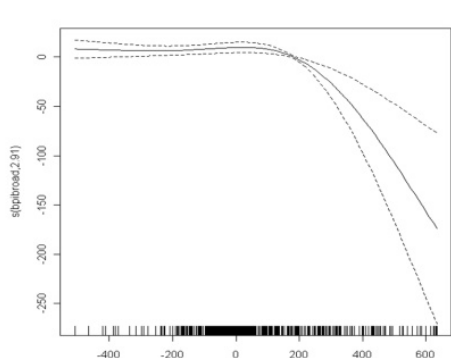
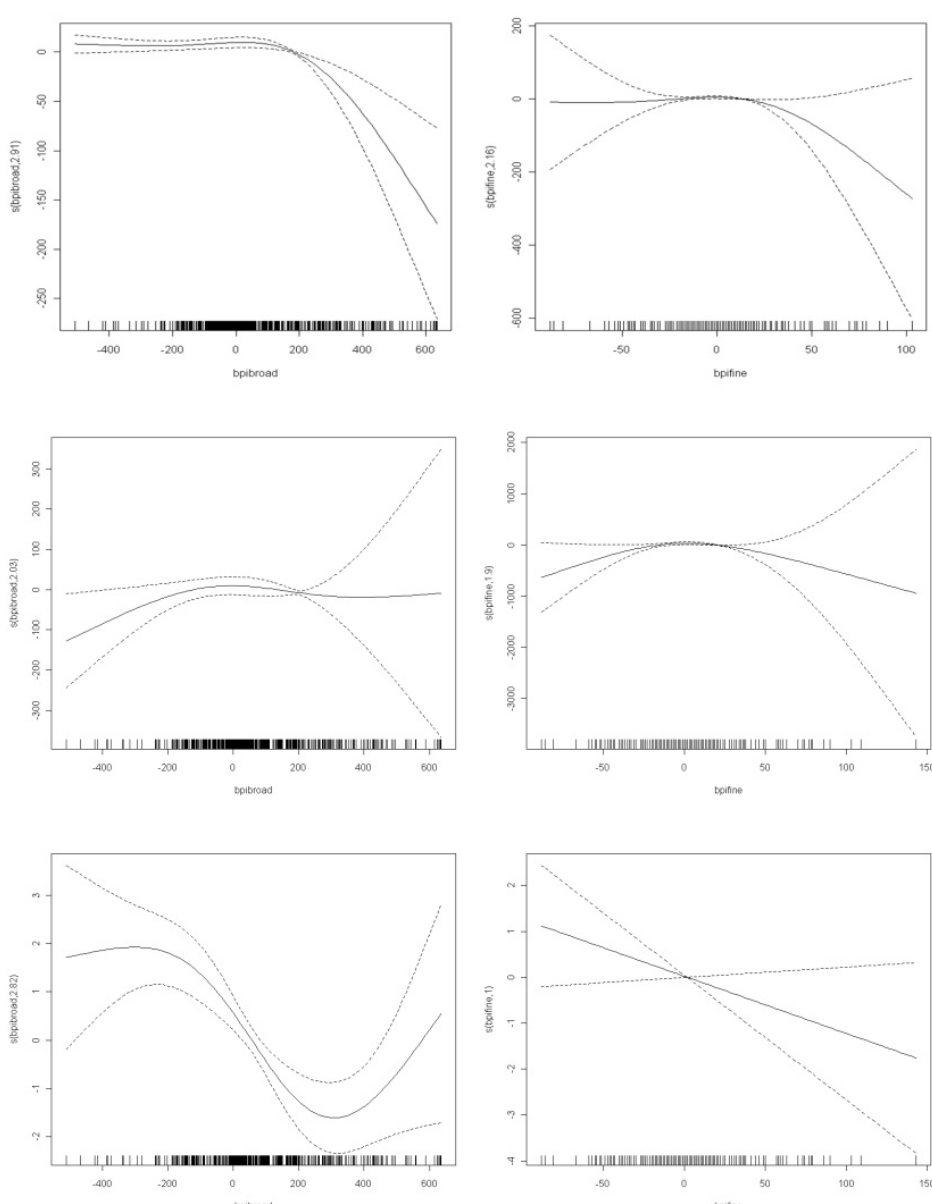
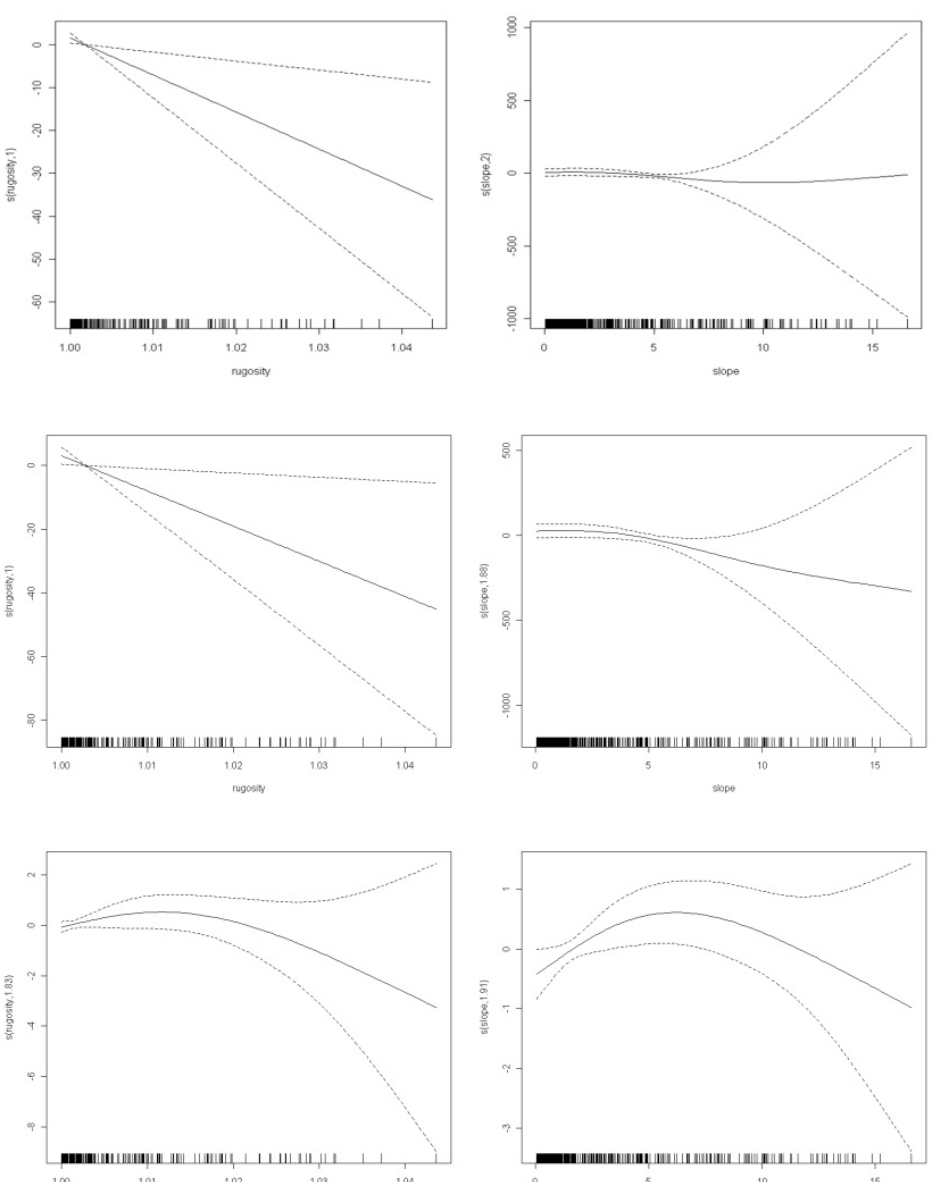
Figure S2 Confidence Maps
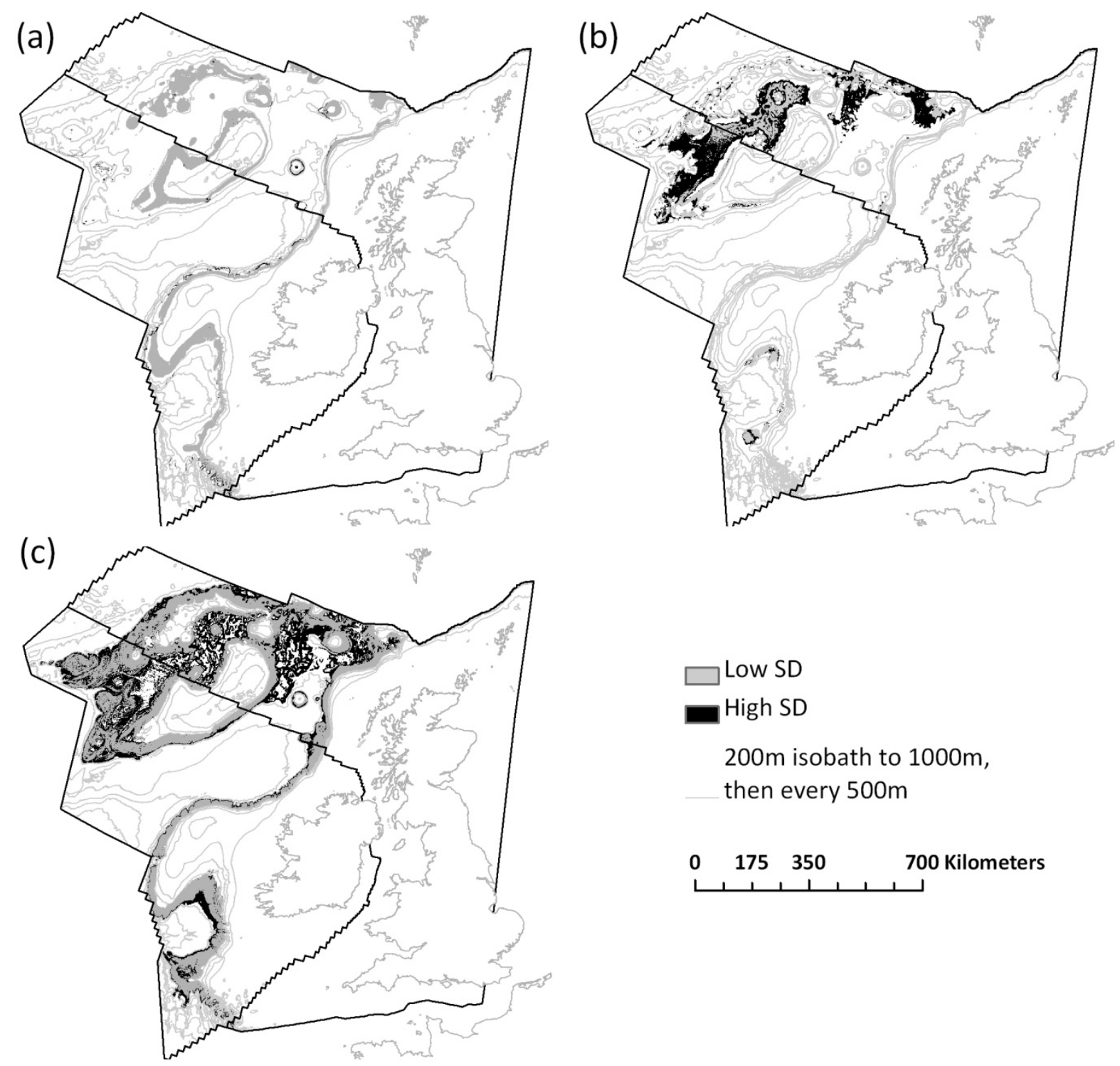

$\square$ Low SD

- High SD

$200 \mathrm{~m}$ isobath to $1000 \mathrm{~m}$, then every $500 \mathrm{~m}$

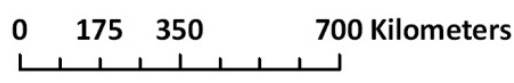

